\title{
6 Imagining Posthuman Environments in the Anthropocene
}

\author{
The Function of Space in Post- \\ Apocalyptic Climate Change Fiction
}

\section{Carolin Gebauer}

The age of the Anthropocene is characterized by a growing awareness of the possible catastrophic consequences of anthropogenic climate change. ${ }^{1}$ This ecological concern is being increasingly dealt with in climate-change or "Anthropocene" (Trexler) fiction that evokes post-apocalyptic scenarios brought about by a combination of natural as well as anthropic causes. ${ }^{2}$ Nature qua environmental materiality plays a major role in these narratives, as it presents a ubiquitous and overwhelming danger for humanity: thunderstorms and hurricanes devastate towns, tsunamis and tidal floods threaten seaports, wildland fires destroy suburban settlements, and earthquakes raze high-rise city buildings. ${ }^{3}$ By presenting nature as an autonomous force that serves as an antagonist to human civilization, post-apocalyptic Anthropocene fiction creates storyworlds in which the human species struggles to survive. ${ }^{4}$ The typical setting of these climate change novels thus constitutes what I will describe as a posthuman environment- that is, a space that gradually obliterates humanity while still being affected by its previous actions. $^{5}$

Being generally located at the intersection of literary criticism, historicism, and critical theory, work on Anthropocene fiction has mainly focused on thematic aspects of the genre rather than its structural or formal features. Only recently did narrative theorists start to investigate the narrative form of climate change fiction, ${ }^{6}$ with the result that the analysis of genrespecific narrative strategies, such as the representation of time and space, plot development, and the narrative situation, has received relatively little attention so far. This previous neglect of a narratological perspective tends to sideline the fact that climate change novels produce what Brian McHale calls "models for the world"-that is, alternative possible worlds which deviate from reality. As the vision of the posthuman transcends lived experience, literature and other forms of art are vital cognitive tools that allow us to come to terms with unknown worlds. Anthropocene fiction, in particular, helps readers to conceive of the elusive notion of the posthuman 
predominantly through its spatial structure. So far, however, narratology has not yet provided any models to adequately describe how such posthuman space may be staged in the novel.

This chapter investigates how climate change fiction allows readers to become immersed in imaginative environments which offer what Marco Caracciolo would characterize as "new 'story-driven' experiences" of the Anthropocene (Experientiality 5). Taking Margaret Atwood's Oryx and Crake as an example, I will explore the specific narrative strategies climate change narratives deploy to portray their setting as a posthuman space which poses a serious threat to survivors. More specifically, by drawing on Yuri M. Lotman's classical model of the spatial structure of narrative texts, I will show that posthuman storyworlds lack semantically charged subspaces or concrete fictional places which, thanks to their different symbolic meaning, divide the storyworld into two parts. The spatial semantics of Anthropocene fiction has important implications for narrative design: even though the absence of symbolic subspaces impedes the development of a complex plot, these texts resort to a series of other effective narrative techniques to convey their story to the reader. As my close reading of Atwood's novel will reveal, post-apocalyptic climate change fiction makes use of two strategies: internally focalized descriptions and analepses (i.e., flashbacks). ${ }^{7}$ The former serve to specify the storyworld from the perspective of a specific character, encouraging readers to become immersed in this imaginary space, whereas the latter detail moments from the characters' pasts before the natural disasters have taken place. Since these flashbacks refer to a storyworld that still contains two symbolic subspaces, they facilitate more sophisticated plot configurations. I will argue that it is only through these descriptive passages and anachronies that post-apocalyptic climate change narratives eventually exhibit a certain degree of tellability (or noteworthiness) and thus the potential to sustain the reader's interest.

\section{The Semantics of Space in Narrative Fiction: Lotman's Classical Model}

One of the earliest approaches to the systematic study of spatial configurations in narrative texts is Yuri M. Lotman's semantics of space, a theory inspired by the works of Russian formalism. In The Structure of the Artistic Text, Lotman attributes significant value to the cultural function of the concept of space. Anticipating the work of contemporary cognitive scholars who emphasize the relevance of spatial metaphors in human thought processes, ${ }^{8}$ he contends that "the language of spatial relations turns out to be one of the basic means for comprehending reality" (218). The reason for this, he argues, is that we tend to draw on spatial concepts to "[construct] cultural models with completely non-spatial content" (218). Every culture produces an individual image of the world in which topological distinctions (e.g., high-low, right-left, near-far) translate into 
binary opposites that have a particular semantic meaning (e.g., valuable-not valuable, good-bad, accessible-inaccessible) as opposed to a merely spatial one. For Lotman, topological characteristics therefore represent essential features of the different conceptualizations of the world shared by specific cultures: "The most general social, religious, political, and ethical models of the world, with whose help man comprehends the world around him at various stages in his spiritual development, are invariably invested with spatial characteristics" (218).

Our understanding of reality by means of spatial relations, Lotman continues, also underlies the structure of artistic texts. As he demonstrates in a detailed analysis of a series of examples from Russian poetry, literary texts produce distinct spatial models, so-called topoi (231), which function in analogy to those spatial world constructions we resort to in order to comprehend reality (218-29). Literary texts, consequently, can be divided into two distinct subspaces which are not only topologically distinct (e.g., top-bottom, right-left, inside-outside), but also semantically polar (e.g., good-evil, familiar-strange, natural-artificial). The semantic topology of worlds represented in literature concretizes in specific topographical opposites (e.g., town/safety-forest/danger, mountain/repose-valley/stress, heaven/good-hell/evil), and these subspaces are separated by a boundary which, according to Lotman, constitutes the most essential topological feature of the text: "The boundary divides the entire space of the text into two mutually non-intersecting subspaces" (229), each of which exhibits a completely different internal structure. What is more, the boundary is impenetrable, meaning that the different characters represented in the text belong to either of the two subspaces and are usually not allowed to leave these allocated spaces (230).

Yet the "spatial continuum of a text" (231) forms not only a certain topos but may also influence a text's classification as a specific text type. ${ }^{9}$ Lotman considers the existence of two symbolically charged spaces which are separated by an impenetrable boundary as a structural prerequisite for narrative (240). Although he does not use the term narrative explicitly, his elaborations clearly imply that he has this specific discourse type in mind. Drawing on the concept of plot, frequently considered one of the most important distinctive features of narrative, ${ }^{10}$ he distinguishes between two types of texts: plotless texts and plotted texts (232).

Lotman understands plot as the global structure of the storyline presented in a specific text. At the heart of each plot construction, he argues, lies its "smallest indivisible unit" (232), the event, which he defines as "the shifting of a persona across the borders of a semantic field" (233). Plotless texts-that is, descriptive texts like calendars, telephone directories, and lyric poemslack such an event, for they exclusively contain immobile elements (e.g., names or dates) or characters (e.g., the lyric persona) that cannot violate any fixed text-internal structure (236). Plotted (or rather narrative) texts, on the other hand, feature at least one mobile character, the so-called hero-agent 
(240), who can move across the different semantic spaces established by these texts because he or she is able to cross the seemingly impenetrable boundary separating these subspaces (238).

Lotman's theory states that a text can only develop specific narrative dynamics if it includes the crossing of a conceptual boundary between two symbolic subspaces on the part of the protagonist: "a plot can always be reduced to a basic episode - the crossing of the basic topological border in the plot's spatial structure" (238). However, as Matías Martínez and Michael Scheffel point out, Lotman discusses as instances of narrative not only texts in which a boundary crossing is successfully executed but also texts in which this event fails or is eventually reversed (142). On the basis of this observation, Martínez and Scheffel reason that, contrary to Lotman's contention, it is not so much the occurrence of the event itself which constitutes a mandatory element of narrative as the existence of a semantic field which is divided into two complementary subsets by a conceptual boundary (140).

At first glance, this implies that Lotman's model of the spatial structure of narrative texts anticipates David Herman's claim that the aspect of space "plays a crucial, not an optional or derivative, role in stories" (Story 264). "[Spatial] reference," Herman stresses, "helps constitute narrative domains" (285; italics in original), as it allows readers to construct mental models of fictional worlds which have a specific spatial structure (264). Herman's insistence on the significance of narrative space forms a stark contrast to classical, or structuralist, approaches to narrative, which consider temporality the cornerstone of narrative (266-67). Indeed, by foregrounding spatial configurations of narrative texts, Lotman attaches greater importance to narrative space than his structuralist contemporaries do. At the same time, he works with a far broader definition of narrative space than Herman or most postclassical narratologists. In Herman's understanding, the category of diegetic space relates exclusively to the physical setting of a narrative (263-99); for Lotman, on the other hand, narrative space is always bound up with a set of ethical, social, and cultural values that are negotiated by the narrative. He thus apprehends contemporary work on the concept of "sense of place" in narrative, which brings forward the argument that narrative space may adopt a pronounced experiential quality for both fictional characters and flesh-and-blood readers (see Caracciolo, "Narrative Space"; Easterlin 111-51). Nonetheless, Lotman's conceptualization of narrative still displays a clear bias toward temporality since, in his theory, space predominantly functions to facilitate the development of a plot.

By making the distinctive quality of the narrative discourse mode conditional on the possibility of a plot, Lotman disregards that a text's narrativity involves more than just a specific aspect of event sequencing. ${ }^{11}$ More complex definitions, such as those advanced by Herman (Basic), Marie-Laure Ryan ("On the Theoretical Foundations"), and Werner Wolf ("Narrative"), each offer a list of different criteria a story may exhibit in order 
to be conceived as narrative. Synthesizing these "multidimensional accounts" of narrative, Caracciolo provides an overview of the most important "basic elements of narrative" (Herman's formulation) or "narratemes" (Wolf's term) that feature in each of these definitions (Caracciolo, Experientiality 31). Accordingly, a text (or any other type of semiotic object) is likely to be perceived as a narrative if it (1) enables the reader to imagine "a storyworld populated by characters and structured around a specific temporal-causal logic;" (2) displays "a certain degree of thematic coherence;" (3) presents events which diverge from the reader's expectations, meaning that the story can be regarded as "being worth telling;" and (4) concentrates on representing "the experiences and evaluations of one or more anthropomorphic entities" (32). ${ }^{12}$ As Caracciolo's synopsis of multilayered definitions of the narrative discourse mode reveals, the quality of being narrative depends on an interplay of various factors, including temporality, sequentiality, and causality, spatiality as well as "tellability" (see Baroni) and "experientiality" (see Caracciolo, Experientiality; Fludernik, Towards). Against this backdrop, then, the category of plot can be conceptualized as a narrative phenomenon which emerges from the functional interaction of these factors. Depending on the specific circumstances given in a narrative, this combination may either emphasize eventfulness or not. ${ }^{13}$

These considerations inevitably challenge Lotman's argument that a story's narrativity hinges exclusively on the existence of a plot that evolves from the text's spatial semantics: does the spatial structure as outlined by Lotman's semantics of space really constitute an indispensable characteristic of narrative? What happens if a novel does not evoke a spatial model that conforms to this particular structure? More precisely, what happens if a narrative constructs a storyworld which does not provide at least two symbolic subspaces that divide the narrative's setting into different parts, thus defying the existence of any conceptual boundary between such spaces? Are these narratives still able to facilitate the development of a plot? If not, which other narrative strategies do these texts deploy to compensate for this lack of eventfulness and to prevent losing the reader's interest in the story? The following close reading of Margaret Atwood's Oryx and Crake will deal with these questions.

\section{The Spatial Structure of Post-Apocalyptic Climate Change Fiction: Margaret Atwood's Oryx and Crake}

\section{Posthuman Spaces}

Published in 2003, Oryx and Crake is the first novel in Margaret Atwood's MaddAddam trilogy. ${ }^{14}$ Combining the voice of a covert thirdperson narrator with the fixed internal perspective of the protagonist, ${ }^{15}$ the narrative recounts the fate of Snowman (formerly known as Jimmy), who seems to be the last human survivor of a viral plague on Earth. Prior 
to the onset of the novel, Snowman's friend Crake initiates a worldwide epidemic by inventing and distributing a lethal and highly infectious virus. Snowman is not affected by the pandemic, though, for Crake has secretly injected him with a vaccine, making him immune to this bioterrorist attack. Crake saves Snowman because he has chosen him to take care of the Crakers, a group of immortal, albeit simple-minded, human-like mutants whom Crake created in his laboratory to succeed humanity. After the apocalypse, Snowman (in accordance with his friend's wishes) guides Crake's "children" from the laboratory to a safe place in open nature, where they settle down.

The post-apocalyptic world in which Snowman and the Crakers now coexist does not resemble the world as the protagonist knows it from his former life. Previously inhabited places such as cities, towns, and gated communities have turned into abandoned, decrepit spaces. Due to climate change and global warming, the Earth has, moreover, metamorphosed into a tropical site where the hot weather never changes (regardless of location). Yet the novel's setting offers anything but idyllic beach holiday scenery; on the contrary, it constitutes a nightmarish space which constantly challenges human existence. Not only does Snowman's new living environment confront the protagonist with regular attacks by wild animals such as genetically manipulated boars ("pigoons") and dogs ("wolvogs"), but his surroundings themselves also pose a threat to him: the "evil rays" (37) of the "punishing sun" (6) burn his skin, "[t]he forest blots up his voice" (169), and the heat turns his brain into "melted cheese" (283). Nature is personified as a deadly enemy against whom the human species does not stand any chance of survival. Snowman accordingly has to admit to himself that he is "the last Homo sapiens - a white illusion of a man, here today, gone tomorrow, so easily shoved over, left to melt in the sun, getting thinner and thinner until he liquefies and trickles away altogether" (224; italics in original).

However, not only does the posthuman space in Oryx and Crake corrupt the human body, it also destroys material aspects of human culture. The "semi-flooded townhouses" of "minnow city" (148) are suggestive of a previous deluge which has already inundated entire building complexes, while the uncontrolled proliferation of vegetation has started to eliminate the last remainders of human civilization:

The buildings that didn't burn or explode [during the time of the riots immediately following the apocalypse] are still standing, though the botany is thrusting itself through every crack. Given time it will fissure the asphalt, topple the walls, push aside the roofs. Some kind of vine is growing everywhere, draping the windowsills, climbing in through the broken windows and up the bars and grillwork. Soon this district will be a thick tangle of vegetation. 
The quotation illustrates that Atwood visualizes the threatening characteristics of her novel's setting by skillfully exploiting the potential of metaphoric language. Personifying botany in general and vine in particular (see the use of the active verbs thrust, fissure, topple, push, drape, and climb), she presents vegetation as a vital power that slowly, but surely, erases "all visible traces of human habitation" (222). ${ }^{16}$

The way in which the environment is represented in Atwood's novel has an impact on the storyworld's spatial structure. The reason for this is that the spatial expansion of nature in Oryx and Crake dissolves the symbolic boundaries which generally organize our cultural thought patterns. Given that water is flooding entire cities and whole compound districts are overgrown with plant life, nature is everywhere in Atwood's post-apocalyptic storyworld. Its omnipresence threatens to collapse the distinction between the two symbolic subspaces underlying the spatial structure of the narrative. In the present of the narrative's storyworld, the distinction between wilderness and civilization is on the verge of vanishing, with the former absorbing the latter. The semantic difference which is usually associated with these opposites-the opposition between nature and human culture-is about to lose its significance as well.

The only spatial opposition which still seems to be valid in Snowman's world is the topological distinction of "up" vs. "down." He sleeps on a tree because the wild animals which are most dangerous to him cannot intrude upon these arboreal night-quarters. Furthermore, during his "pilfering excursions" (45) through the wilderness in search for food, he climbs up ruins of compound walls or buildings to escape sudden attacks by pigoons or wolvogs. Yet this conceptual opposition does not create different symbolic subspaces, as it cannot be associated with concrete fictional places that divide Atwood's post-apocalyptic storyworld into two parts. Neither does "up" correlate with a specific space, considering that it can mean, for instance, "on a tree," "on the upper level of a building," or "on top of a wall," nor is Snowman always safe when he is 'up,' meaning that neither the jungle canopies nor the remnants of former infrastructures are capable of protecting him from other environmental perils such as thunderstorms and lightning. In a posthuman world, even the most essential boundary between human shelter and wilderness risks becoming invalid.

Ironically enough, although Atwood's post-apocalyptic storyworld appears to be a posthuman space, it is humanity itself that has produced Snowman's living environment in the first place. Both climate change and the biological as well as physical changes to the planet Earth that result from it are caused by human action. Atwood's novel thus raises readers' awareness of the fact that the relationship between the notions of nature and humanity, or nature and (human) culture, goes beyond a simple binary divide. Ecocritical terms like the "mesh" (Morton, Ecological Thought 28-38) or "natureculture" (Haraway) lay stress on the interconnectedness between nature and humanity, postulating that we should construe the two 
concepts as one circulating system rather than two juxtaposed terms (Iovino and Oppermann 454). The reason for this is that humans interact with their environment to such an extent that it is impossible to neatly distinguish humanity from nature and nature from humanity.

Atwood does justice to this insight by illustrating the reciprocity between human action and natural force. As human action increasingly relies on advanced technology (specifically genetic engineering), it not only influences but also tries to control the environment, eventually culminating in the catastrophe. After the apocalypse, however, the situation is reversed, for now it is the environment which has a dramatic impact on humanity. While nature is increasingly expanding, it eliminates the last remainders of human civilization so that the storyworld becomes increasingly inhospitable. Because of their attempt to dominate the environment, humanity has produced a posthuman world which gradually annihilates their own species. This ostensibly paradoxical scenario of Oryx and Crake emphasizes the new materialist stance that we should no longer think of our world as an ecosystem in which humans, as active subjects, are superior to matter, as the sum of all (allegedly passive) objects. Instead, we should acknowledge the "vitality of matter" and question our "habit of parsing the world into dull matter (it, things) and vibrant life (us, beings)" (Bennett vii; italics in original). For in the age of the Anthropocene we can no longer deny that we are entangled with nature, which Atwood so drastically shows us by envisaging Snowman's fate as the seemingly last human being within a posthuman world.

\section{Episodic Plot Structures}

The particular spatial structure of Atwood's text-that is, the fact that it forgoes symbolic subspaces which divide the post-apocalyptic storyworld into different parts-influences the novel's overall "narrative dynamics," or rather its "movement ... from its opening to its end" (Richardson 1). According to Lotman's model, a text's narrativity hinges on the development of a plot or storyline, which, in turn, is realized through the transgression of boundaries. However, by dismantling the hierarchy between humanity and physical matter, Atwood's post-apocalyptic storyworld undermines the preexistent symbolic subspaces of civilization and wilderness, with the result that the act of crossing the boundary between these two spaces becomes irrelevant. With that said, Lotman would probably conclude that the spatial structure of Oryx and Crake does not facilitate a plot, hence diminishing the novel's narrativity.

Indeed, the part of the narrative's storyline which unfolds after the apocalypse is quite basic. Refusing to starve to death, Snowman decides to go on a quest for food which leads him back to the headquarters of the RejoovenEsense Compound, the place where Crake planned and initiated the original catastrophe. Snowman's trip back to the end of the world 


\section{Carolin Gebauer}

(ironically referred to as Paradice) can be divided into brief episodic tales, the majority of which are marked by one or several consecutive chapters. These episodes can be summarized as follows:

- Episode 1 (Chapter "RejoovenEsense"): Upon his arrival at the compound, Snowman first comes across an abandoned house in which he searches for food (227-33).

- Episode 2 (Chapter "Twister"): Setting off on his way again after searching the house, Snowman is surprised by a twister, from which he takes shelter in a former checkpoint building, where he also spends the night (234-38).

- Episode 3 (Chapters "Pigoons" and "Radio"): When he wants to continue his journey to Paradice the next morning, he is chased by pigoons, which causes him to again take refuge in the tower of the checkpoint building, where he finally finds some food and beverages (265-74).

- Episode 4 (Chapters "Rampart," "Pleebcrawl," and "Crake in Love"): After spending another night in the checkpoint building, he resumes his journey on top of the rampart surrounding the compound, where he is caught in a thunderstorm $(275-80,283-84,307)$.

- Episode 5 (Chapters "Bubble" and "Scribble"): He eventually arrives in Paradice, where he searches for nourishment and attends to the cut under his foot which he has sustained during his trip (333-38).

This synopsis shows that Atwood's novel features a "tour structure," one of the oldest forms of narrative and one which we know from early genres such as the epic narrative, the medieval romance, and the picaresque novel (Ryan et al. 31-32). As the story follows Snowman's expedition through the postapocalyptic wilderness, it is the temporal course of his journey (rather than causality) that determines the narrative's unfolding: the different episodes are arranged in a chronological order, yet they are not causally connected. As a result, it makes no difference in which order the events occur, meaning that they are randomly interchangeable (except for the first and last episodes, of course, which logically mark the beginning and ending of the trip).

By resorting to the tour structure to present Snowman's trip to the end of the world, Atwood's novel defies the notion that narratives are designed around a particular temporal-causal logic constituting their plot. According to definitions of narrative which emphasize plot, narrative texts usually feature "motivated actions" which fulfil the following criteria: (1) they "involve anthropomorphic agents;" (2) they "are interrelated not only by chronology but also by causality and teleology;" and (3) they "lead to, or are consequences of, conscious acts or decisions, frequently as results of conflicts" (Wolf, "Description" 24). The events depicted in the account of Snowman's quest meet only the first criterion, as Snowman is an anthropomorphic agent who actively decides what to do. However, 
since he moves within a posthuman environment, he can no longer influence the impact of his actions. For, due to the lack of symbolic spaces in the post-apocalyptic diegesis, ${ }^{17}$ there are no longer any socio-cultural structures which might allow him to anticipate the consequences of his deeds and to manipulate his nonhuman adversaries accordingly: he can neither protect himself from attacks by wild animals nor circumvent the forces of nature. His actions have no impact whatsoever, which means that the different events which happen to him are neither mutually dependent, in the sense that one event causes the other, nor do they work toward a specific closure: after his excursion to Paradice, Snowman simply returns to the Crakers and the shelter of his familiar tree.

Strikingly, this lack of teleology is additionally reflected by the novel in that the very first and the very last chapters commence in exactly the same way (except for one omission at the beginning of the novel's last chapter, which is reproduced in the following quotation):

Snowman wakes before dawn. He lies unmoving, listening to the tide coming in ..., wish-wash, wish-wash, the rhythm of heartbeat. $\mathrm{He}$ would so like to believe he is still asleep.

On the eastern horizon there's a greyish haze, lit now with a rosy, deadly glow. Strange how that colour still seems tender.

The absence of any teleological structure demonstrates that Lotman's theory of the semantics of space-namely that plot depends on spatial structurealso applies to Atwood's novel. Since the post-apocalyptic storyworld does not exhibit any subspaces of socio-cultural relevance, the protagonist's human deeds and actions remain insignificant in the context of his inhospitable living environment. By impeding the development of a complex plot in which events are causally linked to lead to a certain outcome, Atwood's novel defies any sense of eventfulness and thus violates an important core trait of narrative. Contrary to Lotman's implications, however, the fairly simple event structure of Atwood's text does not necessarily entail that Oryx and Crake does not qualify as a proper narrative. As I have argued above, the category of plot per se does not constitute an essential "narrateme" or "basic element of narrative." In the remaining part of this essay I will therefore investigate the other narrative properties displayed by Atwood's novel.

\section{Dynamic Descriptions}

Refraining from presenting a complex plot in which events are causally intertwined to fit a certain teleology, Snowman's quest predominantly serves to depict the post-apocalyptic setting of Atwood's storyworld. The account of Snowman's trip consequently contains numerous long passages 


\section{Carolin Gebauer}

of description, which allow the reader to form a rich mental image of the posthuman space in Atwood's novel. As the following examples serve to illustrate, the majority of these descriptive passages are internally focalized, with Snowman serving as the focalizer: ${ }^{18}$

\section{Quotation 1}

After an hour of walking, Snowman comes out from the former park. He picks his way farther inland, heading along the trashed pleebland boulevards and avenues and roads and streets. Wrecked solarcars are plentiful, some piled up in multi-vehicle crashes, some burnt out, some standing intact as if temporarily parked. There are trucks and vans, fuel-cell models and also the old gas or diesel kind, and ATVs. A few bicycles, a few motorcycles-not a bad choice considering the traffic mayhem that must have lasted for days. On a two-wheeled item you'd have been able to weave in and out among the larger vehicles until someone shot you or ran into you, or you fell off.

\section{Quotation 2}

The walking has become an obstacle course for Snowman: in several places he's needed to make detours. Now he's in a narrow sidestreet, choked with vines; they've festooned themselves across the street, from roof to roof. Through the clefts in the overhead greenery he can see a handful of vultures, circling idly in the sky.

(223-24; my emphasis)

\section{Quotation 3}

Up ahead, the houses thin out and vanish. There's an interval of parking lots and warehouses, then barbed wire strung between cement posts, an elaborate gate off its hinges. End of urban sprawl and pleeb city limits, beginning of Compound turfdom.

Snowman's perception of the urban wasteland of a former city ("pleebland") is conveyed to the reader by means of a strategy which, in cognitive linguistics, is known as "route perspective" (Fludernik, "Description" 466) or "tour strategy" (Ryan, "Cognitive Maps" 218). That is to say, the narrative enables the reader to adopt Snowman's point of view by positioning him or her "within the described space ... as a moving focal point" (Fludernik, "Description" 466). As it permits us to join Snowman on his forays through the post-apocalyptic storyworld, the narrative offers us a virtual tour through the abandoned city: it first leads us through the main roads of the city's periphery (Quotation 1 ) and subsequently guides us 
through the narrow sidestreets of the centre (Quotation 2); after traversing the entire inner-city area, we eventually reach the suburbs, which give way to more rural compounds again (Quotation 3).

This dynamic walking tour influences the ways in which we can become immersed in the novel's storyworld. Immersion is an act of imagination which takes place during the process of reading fiction when readers mentally project themselves into the fictive worlds evoked by these texts (Ryan, Narrative 61-114). The strategy of the route perspective intensifies this experience, as it draws on what David Herman refers to as "projective locations" (Story 280-82): representations of space that rely less on the invariant geometric properties of objects ("topological locations") than on the orientative framework of their viewer. Projective locations, Herman explains, do not provide a topological description of the textual world, which would resemble looking at a static map, but rather create the impression that the reader is being led through the mapped area. In lieu of giving an aerial—or at least elevated-view of narrative space, projective locations present a narrative's storyworld from an on-the-ground perspective internal to that world. Erin James therefore argues that this specific strategy of spatial representation "draws readers into the locality of the text" (58) and thus encourages them to experience the imaginary places represented in the narrative as if "being physically in them" (153; italics in original).

The immersive impact of projective locations also extends to Atwood's representation of the post-apocalyptic storyworld in Oryx and Crake. Because the novel makes us follow Snowman's path through the city, it induces us to perceive this place at street-level. We come to know that the entire pleebland infrastructure is covered with smashed or burnt vehicles which are still reminiscent of a former "traffic mayhem," whereas the city centre has already turned into an impassable area which is overrun with botany and frequented by vultures. By creating this atmosphere of urban devastation and decay, Atwood's depiction of Snowman's environment allows readers to get a vivid idea of this place.

The linguistic make-up of the text further strengthens this sense of readerly immersion. Since Snowman's trip through the post-apocalyptic storyworld is relayed in the present tense, the narrative creates the impression of immediacy which enables readers to directly transport themselves into the here-and-now of this world and right onto the narrative scene. This effect, which I designate as the immersive function of present-tense narration (see Gebauer, Chapter 5.3), is reinforced by the narrator's use of the secondperson pronoun at the end of Quotation 1. As James points out, such an intermittent "reference to an unspecified narratee calls out to a hypothetical 'you' that hails all readers, no matter their reading location" (57). The narrator hence invites us to imagine ourselves riding a motorcycle through the traffic chaos. Even if this little thought experiment relates to a point in time which lies before the storyworld's present (i.e., the period shortly after Crake's fatal viral assault when everyone was trying to flee from the city), 
it once more prompts us to imaginatively project ourselves into Snowman's environment.

Although the narrative depicts its setting in great detail and thus grants readers a rich environmental experience, the above descriptions nevertheless neglect to delineate the spatial structure of the diegesis. We merely learn that there are different types of vehicles on the main streets of the city, while the smaller sidestreets are empty and overgrown with vines. When picturing the suburbs, the text, moreover, induces us to imagine parking lots and warehouses as well as the rest of the barbed wire fence that once separated the city from the adjacent compound territory. However, we do not come to know anything about the spatial arrangement of the different vehicles and buildings, nor can we say anything about the individual routes of the different streets. Atwood's depiction of the post-apocalyptic storyworld in Oryx and Crake is remarkably thin on topological information or geographic coordinates, which makes it difficult to derive any concrete cartographic data from it (Ryan, "Cognitive Maps" 219-21). Consequently, if different readers were asked to draw a map of the setting presented in the novel, they would probably come up with completely different places. ${ }^{19}$

From a cognitive perspective, this lack of any map-like specificity fulfils two functions, both of which intensify the readers' immersion in Atwood's storyworld. On the one hand, it foregrounds the internal perspective of the focalizer who travels through this imaginary space. Since readers get a direct insight into Snowman's mind, they can immediately share his perception of his surroundings. Topographical specifications would impede this effect of immediacy, as they would suggest the interference of the heterodiegetic narrator, who has, by definition, an external and elevated view of the storyworld. ${ }^{20}$ This, in turn, would have an impact on readers' imaginative act of projecting themselves onto the narrative scene: if Oryx and Crake featured an overt narrator speaking within the text, readers might well interpret Atwood's use of the fictional present as a referential tense that takes the narrator (rather than the protagonist) as its temporal anchor point (see Gebauer, Chapter 5.2). The present tense would then refer to the narrator's here-and-now on the discourse level-the level of narrative transmission on which the narrator relates the events in retrospect (see Gebauer 187-90)_and the novel would no longer sustain its potential of facilitating readers' imaginative transportation to the diegesis.

On the other hand, the text's lack of spatial orientation emphasizes the fact that topological distinctions (e.g., left-right, front-back) are no longer relevant in the here-and-now of Atwood's storyworld, the sole exception being, again, the differentiation between "up" and "down" (see my emphasis in Quotation 2). This means that cognitive templates based on orientational metaphors (see Lakoff and Johnson), metaphorical blending (see Schneider), or spatial semantics offer little help in the process of naturalizing the postapocalyptic space depicted in this narrative (see Fludernik, "Naturalizing"). Atwood's novel introduces a possible world which clearly interferes with 
readers' tendencies to apply what Marie-Laure Ryan refers to as "the principle of minimal departure" (Possible, Chapter 3). According to this principle-an interpretive rule Ryan establishes to describe how readers may reconstruct textual universes during the process of reading- "we reconstrue the central world of a textual universe in the same way we reconstrue the alternate possible worlds of nonfactual statements: as conforming as far as possible to our representation of AW" (51), that is, the actual world which forms the center of our system of reality. More specifically, this means that when constructing mental models of the worlds evoked in fictional narratives, we "project upon these worlds everything we know about reality," making no adjustments except for those dictated by the texts (51). Oryx and Crake, however, deviates from reality in that its storyworld exhibits a new kind of experientiality (see Caracciolo, Experientiality, Fludernik, Towards): it confronts readers with an unfamiliar experience of space which they do not recognize from real life. Atwood's representation of the post-apocalyptic diegesis as an inhospitable environment thus creates an impression of nonhuman materiality which readers can not only comprehend, but also experience first-hand through the act of reading.

\section{Anachronies}

So far, my analysis of Oryx and Crake has shown that the account of Snowman's adventures contains many "dynamic descriptions" (Wolf, "Description" 24) which detail his journey through "No Man's Land" (Oryx and Crake 353). Since the main function of these descriptive passages is to increase narrative immersion, they stimulate readers to mentally transport themselves into Atwood's post-apocalyptic storyworld. If readers allow themselves to perform this act of mental projection, the text rewards them with a new environmental experience: they can imaginatively move within a posthuman space which is unfamiliar to them because it conflicts with the common spatial thought patterns according to which humans try to make sense of the world. This effect of an alien experience of space becomes even more explicit when comparing the information we have of the protagonist's current environment to what we know about the spatial structure of the preapocalyptic storyworld. In addition to the quest motif (i.e., Snowman's trip to Paradice in search of food), the novel contains a second plot that reveals Snowman's backstory-his life before the apocalypse. The quest part of the novel, which happens in the here-and-now of the storyworld, is written in the present tense. All information on the storyworld's past is inserted into this present-tense account by means of a series of flashbacks that Snowman experiences while wandering through the post-apocalyptic landscape. ${ }^{21}$

Interestingly enough, the design of these analepses is distinct from the passages that are set in the diegetic present. Not only are Snowman's reminiscences written in the past tense rather than the present tense, ${ }^{22}$ but they also depict a storyworld which has not yet transformed into a posthuman 


\section{Carolin Gebauer}

space and which is therefore completely different from Snowman's hereand-now. Before the apocalypse, the world is defined by bio-engineering, and private research corporations assume power over the rest of humanity. Rich people and elite researchers can afford to live in compounds guarded by private companies, whereas mediocre professionals are made to reside in modules (i.e., less secure gated communities). Everybody else has to live in the pleeblands, the crowded cities in which violence and crime prevail. The privately organized compounds and modules are associated with wealth, scientific knowledge, authority, and order; the insecure public pleeblands, on the other hand, involve poverty, scientific incompetence, inferiority, and chaos. Since the pre-apocalyptic storyworld of Oryx and Crake can thus be divided into two different symbolic spaces, the conventional structure of narrative space is still intact.

Within this ordered spatial structure, human characters try to break out of their allocated spaces because they want to climb up the social ladder. A case in point is Jimmy's (i.e., Snowman's) best friend Crake, who manages to work his way up to the top of this hierarchy. When Jimmy and Crake live together in the OrganInc Compound, they go to the same school. After graduation, however, their ways part, for both enter different colleges. While Jimmy leaves home to study at a less prestigious university, Crake continues his education at one of the most highly esteemed academies, which eventually enables him to gain access to the RejoovenEsense Compound, "one of the most powerful Compounds of them all" (252). It is only in this elitist place that Crake can implement his vision of a "better" posthuman species (i.e., the Crakers) and instigate his fatal bioterrorist attack on the (human) world population. In contrast to the present-tense passages, the past-tense analepses consequently allow for the development of a complex plot which shows the reader how the unethical and unscrupulous approval of all forms of genetic engineering eventually brings about the extinction of the human species. The events of this plot are not only linked chronologically but also causally, ultimately leading to one and the same irreversible goal: the apocalypse. By introducing the pre-apocalyptic diegesis as a space that consists of symbolic subspaces which imply different degrees of power and human agency, Snowman's reminiscences compensate for the simple quest motif brought forth by the posthuman environment in Snowman's hereand-now: given that the numerous flashbacks depict a boundary crossing on the part of Crake, they yield a second storyline which fulfils the criteria of narrative along the lines of that described by Lotman.

\section{Conclusion}

As I have sought to demonstrate in this essay, post-apocalyptic climate change fiction integrates the notion of the posthuman by means of its spatial structure. More specifically, my reading of Oryx and Crake has shown that Atwood's narrative imagines a world where the entire 
biosphere turns against human civilization. Rather than constructing different symbolic subspaces, the novel establishes a single homogenous space in which topological and semantic (and, to a certain extent, also topographical) distinctions lose their significance in terms of the classical model posited by Lotman. This particular structure of narrative space has two main effects. The first is the creative manipulation of cognitive templates. Oryx and Crake lacks concrete spatial orientation, to the point that readers need to largely refrain from common interpretive principles like orientational metaphors or spatial semantics when imagining the world depicted in this text (the sole topological aspect of space that still retains some significance is the dichotomy "up" vs. "down"). Secondly, this spatial structure has an impact on the narrative dynamics in Atwood's novel. The protagonist's quest for survival is depicted as a chronological sequence of events which, however, do not form a genuine plot where one event causes the other. Instead, we are faced with a series of interchangeable episodesrandomness seems to have replaced the principle of causality. ${ }^{23}$ In lieu of presenting a complex teleological storyline, the account of Snowman's struggle for survival rather focuses on providing a detailed depiction of the post-apocalyptic storyworld. The narrative thus contains numerous instances of long descriptions which specify Snowman's surroundings to the reader.

In his article "Towards a Typology, Poetics and History of Description in Fiction," Ansgar Nünning notes that "in novels description never informs an entire work" (107). Wolf supports this claim ("Description" 50 ), adding that, in the genre of narrative fiction, longer descriptive passages always need to be motivated by the narrative context in which they occur; otherwise these passages risk losing the reader's interest: "descriptions, and in particular extensive ones, tend to interrupt the story-line and are therefore not infrequently skipped by the impatient reader, eager for action and adventures" (54). My analysis of the function of space in Oryx and Crake has illustrated that Atwood's extensive passages of description are motivated by the texts' spatial structure, which is why I believe that Wolf's contention about the motivation of lengthy descriptions in narrative fiction is justified. The notion that "the interest of narrative text can take ... a variety of shapes" (Herman and Vervaeck 111) and is not necessarily dependent on a narrative's story, on the other hand, contradicts his claim that such descriptive passages automatically curtail a novel's narrative interest. In the case of Oryx and Crake, this interest lies in the readers' willingness to make a new-to use Caracciolo's formulation again- "'story-driven' experience" of unfamiliar environments: by offering readers an insight into Snowman's perception of the post-apocalyptic storyworld, Atwood's dynamic descriptions encourage readers to mentally project themselves into this posthuman space and to explore it from within. Thanks to this high degree of experientiality and readerly engagement with Snowman's surroundings, Atwood's narrative does not forfeit its tellability-that is, its 
quality of being considered "worth telling” (Baroni 836) and thus worth reading as well.

Apart from its long passages of internally focalized description, Atwood's novel uses a second strategy to counterbalance the low degree of narrativity of the survival plot. The narrative contains a great number of analepses which refer back to a former storyworld whose spatial structure still yields tellable events. Owing to these flashbacks, which take the form of memories on the part of the protagonist, the narrative eventually introduces a certain "noteworthiness" (Baroni 836) even with regard to its story. In the light of these findings, then, one could conclude with McHale that Anthropocene fiction can function as a sophisticated and effective model for the world: not only does it warn readers of possible consequences of anthropogenic climate change but it also helps them, in a surprisingly illustrative way, to visualize the inconceivable notion of the posthuman. Climate change novels hence shine a light on the central function of literature and art, that is, to make the unimaginable imaginable and even representable.

\section{Notes}

1 This essay is a revised and updated version of an argument presented in Gebauer, Chapter 8. I wish to thank Roy Sommer, Ryan Dorr, and the editors of this volume for their insightful comments on earlier drafts of this essay.

2 In their survey article "Climate Change in Literature and Literary Criticism," Adam Trexler and Adeline Johns-Putra state that " $[\mathrm{t}]$ he past two decades have seen an increasing amount of fiction dealing with this issue [i.e., anthropogenic climate change], and a particular explosion in the numbers of such novels in the past 10 years" (186). They substantiate their claim by providing a historical overview of climate change novels which pertain to both genre fiction and literary fiction (186-88). Trexler further examines a considerable number of climate change novels in his monograph Anthropocene Fictions.

3 Although the term nature carries various connotations and implications which this essay does not intend to address (see Morton, Ecology 14-21), I here use the term to exclusively refer to a conglomerate of material entities that make up the environment.

4 Sylvia Mayer distinguishes two different types of climate change fiction: the narrative of catastrophe and the narrative of anticipation. While the former portrays a disastrous future scenario in which climate change has already culminated in a "global climate collapse" (23), the latter depicts a storyworld in which natural disasters (as a consequence of climate change) have not yet happened, but are nevertheless realistically conceivable in light of the environmental conditions depicted. The focus of this chapter restricts itself to the former subtype of climate change fiction.

5 This essay prefers the term posthuman to the term nonbuman when referring to post-apocalyptic spaces which result from anthropogenic climate change. The reason for this is that the prefix post-insinuates the (former) existence of both humanity and human agency, whereas the prefix non- negates it.

6 See, e.g., Bracke; Caracciolo, "Form, Science, and Narrative," "Notes for an Econarratological Theory;" as well as the contributions in Chihaia et al. and James and Morel (here especially in Part III). 
7 The classical narratological paradigm of narrative fiction distinguishes between the two categories of "narration" and "focalization" (see Genette 212-34 and 185-94, respectively). While the former relates to the question of "who speaks" in a narrative text, the latter refers to the question of "who sees," or more precisely perceives, the events depicted in the text (186). "Internal focalization," then, means that the narrative events are presented from the perspective(s) of one (or several) character(s) involved in the story rather than from the perspective of the narrator, who, being located outside the world of which he or she tells, has an external view of these events (see Rimmon-Kenan 75-78).

8 See Fauconnier, Mappings; Mental Spaces; Lakoff and Johnson; and Turner.

9 Seymour Chatman distinguishes three different text types: description, narrative, and explanation (see Coming to Terms 6-21). For a thorough discussion of the similarities and differences between these text types, see also Herman (Basic 75-104).

10 For a comprehensive survey of narratological studies that treat plot as "a key constituent of narrative," see Kukkonen (here 715).

11 According to $\mathrm{H}$. Porter Abbott, the term narrativity can signify either "the 'narrativeness' of narrative" or "the 'narrativeness' of a narrative" (587; italics in the original). While the first use of the term refers "generally to the concept of narrative," the second "[applies] comparatively to particular narratives" (587). I here use the term in the latter sense.

12 Since the various multidimensional definitions taken into account by Caracciolo constitute descriptions of the prototype of narrative, each thereby comprehends the quality of narrativity as a graduated scale that covers all possible degrees ranging from high to low (Wolf, "Narrative" 183).

13 Peter Hühn distinguishes two types of events: the type I event and the type II event. While the former "is treated as a defining feature inherent to every kind of narrative," the latter "is integral to a particular type of narrative, providing the foundation for its raison d'etre, or tellability" (160). My use of the term eventfulness in this essay always refers to type II events.

14 In addition to Oryx and Crake, Atwood's popular novel series comprises The Year of the Flood and MaddAddam, published in 2009 and 2013 respectively. Both sequels exhibit a different spatial structure than the first installment in the trilogy as they evoke a storyworld in which human civilization and its concomitant cultural spaces either still exist (The Year of the Flood) or are being reestablished (MaddAddam). Since this chapter, however, is particularly interested in the narrative representation of posthuman spaces that threaten to obliterate humanity, I here confine my discussion of Atwood's work to Oryx and Crake.

15 The category of the "covert narrator," introduced by Seymour Chatman, refers to a narrator who recedes so much into the background that his or her presence is no longer graspable in the text: "In covert narration we hear a voice speaking of events, characters, and setting, but its owner remains hidden in the discoursive shadows" (Chatman, Story and Discourse 197).

16 For a further discussion of Atwood's depiction of the loss of human culture in the post-apocalyptic storyworld of Oryx and Crake, see Gebauer (183).

17 In narratological terminology, the concept of diegesis refers to the storyworld evoked by narrative texts. I here use the terms diegesis and storyworld interchangeably.

18 For a definition of the term focalization, see note 7 .

19 As Ryan points out, any graphic map of a specific narrative world is "only the more or less faithful image of a cognitive map" ("Cognitive Maps" 222), that is, a holistic representation of that world which readers create in order to be able to follow the narrative's plot. It logically follows that individual cognitive maps of 
a particular textual world always differ to a certain degree, for every reader may imagine that very same world differently on the basis of their previous (reading) experiences. Still, it seems safe to assume that the deviation between different mental models of a specific diegesis increases in direct proportion to the text's lack of specificity with regard to the topographies it projects.

20 In his structuralist taxonomy, Gérard Genette distinguishes between heterodiegetic and homodiegetic narrators. While the former are "absent from the [stories they tell]" (244), the latter are "present as [characters] in the [stories they tell]" (245).

21 There is no doubt that Atwood resorts to a narrative pattern here which we also encounter in other post-apocalyptic climate change narratives (Mayer 26). Cormac McCarthy's 2006 novel The Road, by way of example, similarly draws on flashbacks to inform readers of the state of the depicted storyworld before the apocalypse.

22 I have shown elsewhere (see Gebauer, Chapter 8.2) that these tense shifts mainly serve to enhance readers' spatiotemporal orientation within the novel's diegetic universe. However, Atwood's use of fictional tense in Oryx and Crake is not restricted to what I call the referential function of past- and present-tense narration (Chapter 5.2), but she deploys the present tense in various ways, with the result that it fulfills many different functions in her novel.

23 This conclusion is consistent with Caracciolo's argument on "evolutionary plotting" in Kurt Vonnegut's satirical novel Galápagos (see "Posthuman Narration").

\section{References}

Abbott, H. Porter. "Narrativity." Handbook of Narratology, vol. 2, edited by Peter Hühn, Jan Christoph Meister, John Pier, and Wolf Schmid, De Gruyter, 2014, pp. 587-607.

Atwood, Margaret. Oryx and Crake: A Novel. Anchor Books, 2004.

Baroni, Raphaël. "Tellability." Handbook of Narratology, vol. 2, edited by Peter Hühn, Jan Christoph Meister, John Pier, and Wolf Schmid, De Gruyter, 2014, pp. 836-845.

Bennett, Jane. Vibrant Matter: A Political Ecology of Things. Duke University Press, 2010.

Bracke, Astrid. Climate Crisis and the 21st-Century British Novel. Bloomsbury, 2018.

Caracciolo, Marco. The Experientiality of Narrative: An Enactivist Approach. De Gruyter, 2014.

Caracciolo, Marco. "Form, Science, and Narrative in the Anthropocene." Narrative, vol. 27, no. 3, 2019, pp. 270-289.

Caracciolo, Marco. "Narrative Space and Readers' Responses to Stories: A Phenomenological Account.” Style, vol. 47, no. 4, 2013, pp. 425-444.

Caracciolo, Marco. "Notes for an Econarratological Theory of Character." Frontiers of Narrative, vol. 4, no. 1, 2018, pp. 172-189.

Caracciolo, Marco. "Posthuman Narration as a Test Bed for Experientiality: The Case of Kurt Vonnegut's Galápagos.” Partial Answers, vol. 16, no. 2, 2018, pp. 303-314.

Chatman, Seymour. Coming to Terms: The Rhetoric of Narrative in Fiction and Film. Cornell University Press, 1990.

Chatman, Seymour. Story and Discourse: Narrative Structure in Fiction and Film. Cornell University Press, 1978. 
Chihaia, Matei, Sandra Heinen, Matías Martínez, Katharina Rennhak, Michael Scheffel, and Roy Sommer, editors. "Narrative Theory and the Anthropocene." Special issue of DIEGESIS: Interdisciplinary E-Journal for Narrative Research, vol. 9, no. 2, 2020.

Easterlin, Nancy. A Biocultural Approach to Literary Theory and Interpretation. Johns Hopkins University Press, 2012.

Fauconnier, Gilles. Mappings in Thought and Language. Cambridge University Press, 1997.

Fauconnier, Gilles. Mental Spaces: Aspects of Meaning Construction in Natural Language. Cambridge University Press, 1994.

Fludernik, Monika. "Description and Perspective: The Representation of Interiors." Style, vol. 48, no. 4, 2014, pp. 461-478.

Fludernik, Monika. "Naturalizing the Unnatural: A View from Blending Theory." Journal of Literary Semantics, vol. 39, 2010, pp. 1-27.

Fludernik, Monika. Towards a "Natural" Narratology. Routledge, 1996.

Gebauer, Carolin. Making Time: World Construction in the Present-Tense Novel. De Gruyter, 2021.

Genette, Gérard. Narrative Discourse: An Essay in Method, translated by J. E. Lewin, Cornell University Press, 1980.

Haraway, Donna. The Companion Species Manifesto: Dogs, People, and Significant Otherness. Prickly Paradigm Press, 2003.

Herman, David. Basic Elements of Narrative. Wiley-Blackwell, 2009.

Herman, David. Story Logic: Problems and Possibilities of Narrative. University of Nebraska Press, 2002.

Herman, Luc, and Bart Vervaeck. "Narrative Interest and Cultural Negotiation." Narrative, vol. 17, no. 1, January 2009, pp. 111-129.

Hühn, Peter. "Event and Eventfulness." Handbook of Narratology, vol. 1, edited by Peter Hühn, Jan Christoph Meister, John Pier, and Wolf Schmid, De Gruyter, 2014, pp. 159-178.

Iovino, Serenella, and Serpil Oppermann. "Theorizing Material Ecocriticism: A Diptych." Interdisciplinary Studies in Literature and Environment, vol. 19, no. 3, 2012, pp. 448-475.

James, Erin. The Storyworld Accord: Econarratology and Postcolonial Narratives. University of Nebraska Press, 2015.

James, Erin, and Eric Morel, editors. Environment and Narrative: New Directions in Econarratology. Ohio State University Press, 2020.

Kukkonen, Karin. "Plot." Handbook of Narratology, vol. 2, edited by Peter Hühn, Jan Christoph Meister, John Pier, and Wolf Schmid, De Gruyter, 2014, pp. 706-719.

Lakoff, George, and Mark Johnson. Metaphors We Live By. University of Chicago Press, 2003.

Lotman, Yuri M. The Structure of the Artistic Text, translated by Gail Lenhoff and Ronald Vroon, University of Michigan Press, 1977.

Martínez, Matías, and Michael Scheffel. Einführung in die Erzähltheorie. C. H. Beck, 2009.

Mayer, Sylvia. "Explorations of the Controversially Real: Risk, the Climate Change Novel, and the Narrative of Anticipation." The Anticipation of Catastrophe: Environmental Risk in North American Literature and Culture, edited by Sylvia Mayer and Alexa Weik von Mossner, Winter, 2014, pp. 21-37. 


\section{Carolin Gebauer}

McHale, Brian. "Model and Thought Experiments." Why Study Literature? edited by Jan Alber, Stefan Iversen, Louise Brix Jacobsen, Rikke Andersen Kraglund, Henrik Skov Nielsen, and Camilla Møhring Reestorff, Aarhus University Press, 2011, pp. 135-155.

Morton, Timothy. The Ecological Thought. Harvard University Press, 2010.

Morton, Timothy. Ecology Without Nature: Rethinking Environmental Aesthetics. Harvard University Press, 2007.

Nünning, Ansgar. "Towards a Typology, Poetics and History of Description in Fiction." Description in Literature and Other Media, edited by Werner Wolf and Walter Bernhart, Rodopi, 2007, pp. 91-128.

Richardson, Brian. "General Introduction." Narrative Dynamics: Essays on Time, Plot, Closure, and Frames, edited by Brian Richardson, Ohio State University Press, 2002, pp. 1-7.

Rimmon-Kenan, Shlomith. Narrative Fiction: Contemporary Poetics. Routledge, 2002.

Ryan, Marie-Laure. "Cognitive Maps and the Construction of Narrative Space." Narrative Theory and the Cognitive Sciences, edited by David Herman, CSLI Publications, 2003, pp. 214-242.

Ryan, Marie-Laure. Narrative as Virtual Reality 2: Revisiting Immersion and Interactivity in Literature and Electronic Media. Johns Hopkins University Press, 2015.

Ryan, Marie-Laure. "On the Theoretical Foundations of Transmedial Narratology." Narratology Beyond Literary Criticism: Mediality, Disciplinarity, edited by Jan Christoph Meister, De Gruyter, 2005, pp. 1-23.

Ryan, Marie-Laure. Possible Worlds, Artificial Intelligence and Narrative Theory. University of Indiana Press, 1991.

Ryan, Marie-Laure, Kenneth Foote, and Maoz Azaryahu. Narrating Space / Spatializing Narrative: Where Narrative Theory and Geography Meet. Ohio State University Press, 2016.

Schneider, Ralf. "Blending and the Study of Narrative: An Introduction." Blending and the Study of Narrative: Approaches and Applications, edited by Ralf Schneider and Marcus Hartner, De Gruyter, 2012, pp. 1-30.

Trexler, Adam. Anthropocene Fictions: The Novel in a Time of Climate Change. University of Virginia Press, 2015.

Trexler, Adam, and Adeline Johns-Putra. "Climate Change in Literature and Literary Criticism.” WIREs: Climate Change, vol. 2, 2011, pp. 185-200.

Turner, Mark. The Literary Mind: The Origins of Thought and Language. Oxford University Press, 1996.

Wolf, Werner. "Description as a Transmedial Mode of Representation: General Features and Possibilities of Realization in Painting, Fiction and Music." Description in Literature and Other Media, edited by Werner Wolf and Walter Bernhart, Rodopi, 2007, pp. 1-87.

Wolf, Werner. "Narrative and Narrativity: A Narratological Reconceptualization and Its Applicability to the Visual Arts.” Word \& Image, vol. 19, no. 3, 2003, pp. 180-197. 